\title{
Budgetary Allocations to the Agricultural Sector in Nigeria: Implications on Investment and Productivity
}

\author{
Margaret Nseobong Ita ${ }^{1}$, Inibehe George Ukpong ${ }^{2} \&$ Ineye Douglas Ekpebu ${ }^{3}$ \\ ${ }^{1}$ Department of Agricultural Economics and Extension, University of Calabar, Nigeria \\ ${ }^{2}$ Department of Food Economics and Marketing, School of Agriculture, Policy and Development, University of \\ Reading, United Kingdom \\ ${ }^{3}$ Department of Agricultural Extension and Management, Federal Polytechnic, Ekowe, Bayelsa State, Nigeria \\ Correspondence: Inibehe George Ukpong, Department of Food Economics and Marketing, School of Agriculture, \\ Policy and Development, University of Reading, United Kingdom. E-mail: inibehe2000@yahoo.com
}

Received: June 19, 2013 Accepted: August 9, 2013 Online Published: October 15, 2013

doi:10.5539/jas.v5n11p49 URL: http://dx.doi.org/10.5539/jas.v5n11p49

\begin{abstract}
The study analyzed the budgetary allocations to the agricultural sector in Nigeria. The mean difference test, percentages and trend analyses were used to compare the allocations by the Federal and State levels of government. Results show that there was instability in the way budgets were allocated to the agricultural sector, and there was no significant difference between the allocations made to the sector by the federal and state levels of government. The study recommends that the government at all levels should ensure stability and increment in allocation to the agricultural sector to promote growth and development of the sector. The government should ensure proper monitoring and effective service delivery with regards to allocations to the agricultural sector, while farmers should ensure efficient use of allocated resources for agricultural development. Government should also ensure proper implementation of suitable agricultural policies that would promote increased investments and productivity in the sector.
\end{abstract}

Keywords: budgetary allocation, agricultural sector, investment, productivity, Nigeria

\section{Introduction}

Agriculture remains important in the history of economic development in Nigeria. It generates employment for both skilled and unskilled labour, and contributes enormously to national and state gross domestic products. Agriculture helps to provide raw materials to the country's industrial sector and foreign agro allied industry, and enhances both national and state food security. However, there has been a systematic neglect of the sector at both national and state levels since the discovery of crude oil in the country in the 1960s. Agriculture is the major source of livelihood in most rural Nigerian society (IFAD, 2013); hence, neglect of the agricultural sector has opened the way for increased rural poverty, rural-urban migration, hunger and crimes (Iruo, Sogo, \& Ukpong, 2010).

Nevertheless, part of the effort by the government to sustain the country's agricultural sector is evidenced by its various allocations to the sector in terms of lending and budgetary provisions. Budgetary provisions are often made for specific programmes or projects in agriculture, under numerous sub-sectors mainly; crops, livestock, fisheries, and forestry (CBN, 2003).

These allocations are often expended either on physical structures, grants and other inputs distributed to farmers or funding to agencies that perform agriculture-related services. The allocation is normally specified in the government budget. A budget is a financial plan of action to a firm, which provides details of projected inflows and outflows within a stated period of time, and becomes a critical element for effective management decisions (Petershie, 2008). Budgetary allocation is the finances allocated to plan for growth and development of a sector. Budgetary analysis is thus an important tool that helps to promote economic assessment of all sectors of the economy including the agricultural sector, and it is useful for planning and management at the farm level (Abang, Agom, Enyenihi, \& Ele, 2008).

Government budgetary allocations make capital available for agricultural production by helping to secure inputs, technology and management, hence promoting increased agricultural production. Government contributions to the agricultural sector therefore enable capital investments that help in the development and growth of the sector 
(Douillet \& Grandval, 2011). For instance, such allocations can enable increased land size and improvement, as well as increased research in agriculture; hence, budgetary allocations thus have both direct and indirect effects on the production level of food and raw materials and consequently affect the standards of living of the people. In other words, lending and budgetary allocations to the agricultural sector should be increased by the government to help improve the performance of the country's economy (Uzomba, Imoisi, \& Somiari, 2012). This will also promote both local and foreign investments, and agricultural productivity, hence helping to solve economic and food security challenges in the country. Apart from budgetary allocations to the agricultural sector, government policies have also provided opportunity for commercial banks to be involved in credit provisions to the agricultural sector through the agricultural credit guarantee scheme of the central bank of Nigeria, among other schemes (Ebong, 2007).

Specifically, issues of neglect of the agricultural sector characterized by instability in government allocations and insufficient capital to the agricultural sector, as well as inconsistent agricultural policies have received lots of debate since the discovery of oil and gas in Nigeria. For instance, insufficient capital and inconsistent government policies have been identified as part of the major factors affecting growth and development of the agricultural sector (Aja, Chikaire, \& Ejiogu-Okereke, 2010), whereas, capital would not be a problem if adequate funding is made available for agricultural production by the government. Also, allocations to different economic sectors including the agricultural sub-sectors (crops, livestock, fisheries and forestry) are sometimes not released on time, and in some cases diverted and the programmes they were meant for therefore suffer serious neglect and delay. Based on this background, the study aimed to achieve the following objectives; to:

(i) Evaluate the trend of budgetary allocations to the agricultural sector over time by the Federal and State government.

(ii) Determine the statistical difference between budgetary allocations by the federal and state levels of government.

(iii) Proffer policy recommendations based on findings.

It is expected that the recommendations of the study will contribute to existing literature, and will be useful for policy formulation, and decision making on budgets and allocations by the government and other stakeholders to the agricultural sector and other sectors of the economy.

\subsection{Budget Allocations and Implications on Agricultural Development in Nigeria}

A budget is an important tool for economic planning, and becomes necessary to effect good planning because resources are scarce. Thus, budgeting provides an effective mechanism for managing the economy and the scarce resources (Petershie, 2008). Budgetary allocations provide the agricultural sector with factors of production such as capital, labour, land, research and all other resources used in production. Government can co-partner with farmers to enhance provision of funds for agricultural production and technology transfer (Ozor, Chukwuone, Madukwe, \& Garforth, 2007). Allocations and other forms of agricultural (farm) credits including insurance provisions from the government often help to expand scope of operations, research, investment and production in the agricultural sector (Ibitoye, 2012). In Nigeria, government at all levels often makes budget provisions for agricultural development. However, the question remains; to what extent does budget allocations enhance and promote agricultural growth and development in the economy?

In other words, government budgets are often made to stimulate economic growth and target poverty in the economy, but poverty cannot be alleviated especially in the rural areas when agricultural growth and development are still not achieved. This is because the rural economy in Nigeria is almost solely dependent on agriculture (IFAD, 2013). Also, there is a need to give adequate attention and funds to promote basic supportive infrastructure including stable electricity supply, markets, good access roads and affordable transport system, as well as improved agro-allied industry in the country (Ekpebu \& Ukpong, 2012). Thus in analyzing the funds allocated to agriculture at different levels of the economy, there is a need for knowledge of how agricultural activities are fostered with consideration of other support linkages that all-together promote agricultural development.

One major reason for food scarcity and poverty in most developing countries, including Nigeria, is as a result of reduced agricultural production influenced by insufficient capital, poor technology and poor quality inputs, which otherwise would be achieved through increased budgetary allocations under efficient management (Taiwo, 2001). Hence, if funds often allocated to the agricultural sector are often properly utilized, a lasting valuable outcome can be ensured, resulting to a greater positive impact on productivity and economic development in the country.

Indeed, increase in budgetary allocations to the agricultural sector remains a necessary strategy to achieving increased agricultural productivity and poverty reduction. Besides, there is a need for increased integration of other 
sectors to promote increased investment and productivity in agriculture, this may include partnership between the oil and gas industry, the government, banks and farmers to promote agricultural development, and enhance improved livelihood for the people (Ogunlade, Oladele, \& Ogunsola, 2009). Such partnership would promote improved research and technology, as well as provision of sufficient capital and other farm inputs.

On the whole, it is important that for budget to succeed, necessary frameworks should be put in place to promote practicability, compliance, monitoring and adequate implementation by different sectors of the economy. Moreover, government allocations to the agricultural sector should be properly monitored to promote growth and development of the sector, while government should also ensure sustained increase in the allocation of funds budgeted for the agricultural sector as long as such increases are necessary to promote growth of the sector.

\section{Materials and Methods}

Data for this study were obtained from the public domain of the Central Bank of Nigeria (CBN) and Department of Budget and Planning (DBP) of the Governor's office, Cross River State, Nigeria. The data which covered a period between 1997 and 2003 were mainly on annual budgetary allocations to the agricultural sector by the Cross River State and Federal government.

Descriptive statistics including, tables, means and percentages, as well as, the mean difference test were used to analyze data on the budget allocation by the federal and state levels of government in Nigeria. Trend analysis and annual percentage change were also used to show the growth of the allocations over time. The mean difference test was used to determine the significant difference between the allocations made to the agricultural sector by the Federal and State levels of government. The mean difference model has been presented as equation 1 below:

$$
t_{c a l}=\frac{\bar{X}_{1}-\bar{X}_{2}}{\sqrt{\frac{\sum\left(X_{1}-\bar{X}_{1}\right)^{2}+\sum\left(X_{2}-\bar{x}_{2}\right)^{2}}{n_{1}+n_{2}-2}} \cdot \frac{1}{n_{1}}+\frac{1}{n_{2}}}
$$

Where,

$\mathrm{X}_{1}=$ Annual allocations by the Federal Government to the agricultural sector between 1997 and 2003.

$\bar{X}_{1}=$ mean allocations by the Federal Government to the agricultural sector between 1997 and 2003.

$\bar{X}_{2}=$ Mean allocations by the Cross River State Government to the agricultural sector between 1997 and 2003.

$\mathrm{X}_{2}=$ Annual allocations by the Cross River State Government to the agricultural sector between 1997 and 2003.

$\mathbf{n}_{2}=$ Number of years considered for the Cross River State Government allocations.

$\mathbf{n}_{1}=$ Number of years considered for the Federal Government allocations.

The null hypothesis of no significant difference between the allocations made by the Federal Government and those made by the state government to the agricultural sector from 1997 to 2003 was tested at 5 percent level of significance by comparing the calculated $\mathrm{t}\left(\mathrm{t}_{\mathrm{cal}}\right)$ with the tabulated $\mathrm{t}\left(\mathrm{t}_{\mathrm{tab}}\right)$ for $\left(\mathbf{n}_{1}+\mathbf{n}_{2}-2\right)$ degree of freedom.

\section{Results and Discussion}

\subsection{Trends and Real Growth in allocations to the Agricultural sector by the Federal and Cross River State Government}

Table 1. Annual Percentage change and proportion of budgetary allocations to agriculture (1997-2003)

\begin{tabular}{lccll}
\hline Year & $\begin{array}{l}\text { \% Allocation } \\
\text { (Federal) }\end{array}$ & $\begin{array}{l}\text { \% Allocation } \\
\text { (State) }\end{array}$ & $\begin{array}{l}\text { \% Change in CRS } \\
\text { Allocation }\end{array}$ & $\begin{array}{l}\text { \% Change in Federal } \\
\text { Allocation }\end{array}$ \\
\hline 1997 & 4.08 & 2.07 & - & - \\
1998 & 6.09 & 2.53 & 0.46 & 2.01 \\
1999 & 19.68 & 5.77 & 3.24 & 13.59 \\
2000 & 5.45 & 26.14 & 20.37 & $(14.23)^{*}$ \\
2001 & 33.40 & 33.77 & 7.63 & 27.95 \\
2002 & 23.04 & 15.21 & $(18.56)^{*}$ & 10.36 \\
2003 & 8.25 & 14.49 & $(0.72)^{*}$ & 14.79 \\
\hline
\end{tabular}

*. Figures in parenthesis are negative; CRS: Cross River State; \%: Percentage.

Source: Computed from data gotten from CBN (2003) \& DBP (2006). 
Table 1 indicates the annual Percentage change and proportion of budgetary allocations to agriculture by the federal and cross river state government between 1997 and 2003. The result shows that the share (proportion) of allocations by the state government to the sector increased from $2.07 \%$ in 1997 to $33.77 \%$ in 2001 . It then decreased to $15.21 \%$ in 2002 and $14.49 \%$ in 2003 , while that of the federal government increased from $4.08 \%$ in 1997 to $19.68 \%$ in 1999 , after a drop to $5.45 \%$ in 2000 . It however increased to $33.40 \%$ in 2001 and later continued to drop to $23.04 \%$ in 2002 and $8.25 \%$ in 2003 . On the other hand, the table shows that changes in allocation vary from year to year at both levels of government with varying magnitudes of instability. For instance, percentage change in allocation to the agricultural sector by the state changed from $0.46 \%$ in 1998 to as high as $20.37 \%$ in 2000 ; then, dropped to $7.63 \%$ in 2001 and to as low as $-18.56 \%$ in 2002 and -0.72 in 2003 ; while that of the federal government increased from $2.01 \%$ in 1998 to $13.59 \%$ in 1999 , then, dropped to as low as $-14.23 \%$ in 2000 . It later increased to $27.95 \%$ in $2001 ; 10.36 \%$ in 2002 and $14.79 \%$ in 2003 . It is obvious that allocation instability to the agricultural sector often results from changes in government regimes and/or changes in government policies. It can also result from changes in national income per year or policy agenda and interest of a particular government regime, as well as political interest. Reduction in allocation to the agricultural sector which has suffered prolonged neglect could result to poor performance, low productivity and reduced investment in the sector. It is therefore important that a fixed percentage of the national income be specified as annual allocation to the sector, although this may increase where necessary to enhance increased growth of the sector.

From the result, it can also be said that allocation instability was higher in the Federal level than in the state budgets. Instability in allocation sends wrong signals to the sector and the economy, which in turn affects production and investment behavior within the sector. This could be one of the reasons for the slow growth in the country's agricultural sector over time.

\subsection{Mean Difference Test}

Table 2. Summary of the mean difference test

\begin{tabular}{llllllll}
\hline$\sum\left(\mathrm{X}_{1}-\bar{X}_{1}\right)^{2}$ & $\sum\left(\mathrm{X}_{2^{-}} \bar{X}_{2}\right)^{2}$ & $\mathbf{n}_{1}$ & $\mathbf{n}_{2}$ & $\bar{X}_{1}$ & $\bar{X}_{2}$ & $\mathrm{t}_{\text {cal }}$ & $\mathrm{t}_{\text {tab }}$ \\
\hline $16.185 \times 10^{20}$ & $0.00676 \mathrm{X}^{20} 0^{20}$ & 7 & 7 & $2.777 \times 10^{10}$ & $0.0396 \times 10^{10}$ & 8.2439 & 3.0545 \\
\hline
\end{tabular}

Source: Computed from data gotten from CBN (2003) \& DBP (2006).

Table 2 shows the summary result of the mean difference model used to determine whether or not there was any significant difference between allocations to agriculture made by the Federal and Cross River State Government. The result shows that the calculated $t\left(t_{c a l}\right)$ was 8.2439 while tabulated $t\left(t_{\text {tab }}\right)$ was 3.0545 . From the result, since $t_{\text {cal }}$ was greater than $t_{\mathrm{tab}}$, we failed to reject the null hypothesis of no significant difference between the allocations by the two levels of government, hence, concludes that there is no significant difference between the allocations made by the federal government and those by the state government. On the whole, no matter the size of budget allocation, it is only a properly managed and efficiently used allocation that can make a positive impact towards improving agricultural productivity and investment, as well as economic development of a nation.

\section{Conclusion and Recommendations}

In the quest to promote agricultural development, government at both state and Federal levels make annual budgetary provisions to the agricultural sector. In allocating funds, the government is often guided by measures that reflect their various goals. These goals may vary from one government regime to another. Therefore as government change, goals and budgets also change. These changes often affect productivity and investment decisions of both private and public sectors. Government policies have high impact on investment decisions of investors, and growth-enabling policies will also attract investment by both domestic and foreign investors. Hence to enhance effective agricultural development in the country, a sustained and stable growth in allocation to agriculture should be encouraged with adequate policies by all levels of government. This will also enhance increased productivity and in turn contributes to a better living standard of the people at all levels of the economy.

Better still, there is a need for the government at all levels to maintain an increasing trend in budgetary allocations to different sectors of the economy including the agricultural sector, considering the increasing trend in the country's and global population growth which have resulted to increasing demand for food and other agricultural products. 


\section{Acknowledgement}

The authors acknowledge the contributions of Prof. S. O. Abang; who was the academic supervisor during the time of this research.

\section{References}

Abang, S. O., Agom, D. I., Enyenihi, E. A., \& Ele, I. E. (2008). Introduction to Farm Management: Principles, Plans, Budgets and Control. Calabar, Nigeria: King Judah Publishers.

Aja, O. O., Chikaire, J., \& Ejiogu-Okereke, E. N. (2010). Mobilization of Youths for effective participation in Agriculture: Implication for the attainment of Vision 20:2020 in Nigeria. Proceedings of the Sixth International Conference on Sustainable Development, Ibadan, Nigeria, 6(14), 33-37.

BPD. (2006). Budgetary Allocations to Agriculture. Budget and Planning Department, Governor's Office, Calabar, Cross River State, Nigeria.

CBN. (2003). Budgetary Allocations to Agriculture (Volume 14, December). Statistical Bulletin, Central Bank of Nigeria.

Douillet, M., \& Grandval, F. (2011). Nigeria's Agricultural Policy: Seeking coherence within strategic frameworks. Retrieved from http://www.inter-reseaux.org/IMG/pdf/p16-18_Agric_Policy.pdf

Ebong, V. O. (2007). Agribusiness Management in a Developing Economy: The Nigerian Perspective. Uyo, Nigeria: Robertminder International Publishers.

Ekpebu, I. D., \& Ukpong, I. G. (2012). Rethinking Agricultural Development in Nigeria: Paradox of Oil Wealth. Bloomington, USA: Authorhouse Publishing.

Ibitoye, S. J. (2012). Assessment of the levels of awareness and use of Agricultural Insurance Scheme among Rural Farmers in Kogi State, Nigeria. International Journal of Agricultural Science Research and Technology, 2(3), 143-148.

IFAD. (2013). Rural Poverty in Nigeria. Rural Poverty Portal. Retrieved from http://www.ruralpovertyportal.org/country/home/tags/nigeria

Iruo, F. A., Sogo, T. C., \& Ukpong, I. G. (2010). Effect of rural-urban migration on Fisheries development in Bayelsa State, Nigeria: A Case of Yenagoa Agricultural Zone. International Journal of Agricultural Economics and Extension, 2(1), 6-16.

Ogunlade, I., Oladele, O. I., \& Ogunsola, M. B. (2009). Impact of Green River Project on Livelihood of Farmers in Rivers State, Nigeria. J. Hum. Ecol., 26(2), 81-84.

Ozor, N., Chukwuone, N. A., Madukwe, M. C., \& Garforth, C. J. (2007). Cost-sharing of Agricultural Technology transfer in Nigeria: Perceptions of Farmers and Extension Professionals. Journal of Agricultural Education and Extension, 13(1), 23-37. http://dx.doi.org/10.1080/13892240601162072

Petershie, B. E. K. (2008). Management Economics (Revised Edition). Terror Publications, Accra, Ghana.

Taiwo, I. O. (2001). Review and Appraisal of the Year 2000. Federal Government Budget performance. Central Bank of Nigeria Bullion, 25(1).

Uzomba, P. C., Imoisi, A. I., \& Somiari, S. (2012). The Impact of Macroeconomic variables on non-oil exports performance in Nigeria, 1986-2010. Journal of Contemporary Research, 9(1), 1-17.

\section{Copyrights}

Copyright for this article is retained by the author(s), with first publication rights granted to the journal.

This is an open-access article distributed under the terms and conditions of the Creative Commons Attribution license (http://creativecommons.org/licenses/by/3.0/). 